\title{
Body text: the opposition "pure / unclean" in the mythological representations of the Slavs
}

\author{
A. I. Temchenko \\ Bohdan Khmelnytsky National University at Cherkasy, Cherkasy, Ukraine \\ Corresponding author. E-mail: temchen@ukr.net
}

Paper received 10.05.18; Accepted for publication 17.05.18.

https://doi.org/10.31174/SEND-Ph2018-166VI49-12

\begin{abstract}
In mythology, a dual attitude to the body is fixed, which ranges from positive, useful, pure to negative, harmful, unclean. In the first case, the semantic codes determine the processes of conception and birth, in the second, getting rid of impure and superfluous. Mythology of conception correlates with agricultural cults and is represented by the example of the poppy seeds. In the birth rites, the symbolism of the body in certain aspects intersects with the semantic field of the mythological top.
\end{abstract}

The magical actions of getting rid of the unclean are "used" by the rite as a way to destroy the disease.

Ключевые слова: myth, body, poppy, King's gates, sacred patrons.

Recently, in the humanitarian field there have been tendencies to study the mythological semantics of the human body [1]. A characteristic feature of research is the concentration of attention on general issues that relate to the value of the body as a cultural object [2]. At the same time, in most of the works the researchers avoid questions of a "delicate nature" that concern the sexual and excretory system, although it is these parts of the body that are an important factor in shaping the cultural landscape of the Slavs.

The purpose of the article is to study the mythology of the body, which is formed in accordance with its physiological purpose, namely: the functions of fertilization, the birth and allocation of excess, harmful. Accordingly, the relevance of the proposed article is related to the consideration of the semantics of the body within the mythological opposition, which varies within the limits of positive, pure, viable and negative, impure, deadly.

Fertilization. In the mythological picture of the world, the semantic analogies with the plant world are used to taboo the literal names of the genital organs. In particular, in "female magic" the male seed is associated with a small and barely noticeable poppy seed. So, the sowing of this grain (sperma) around the well (vagina), which is carried out in the "male" holiday of Andrey (the time of fortune telling) provokes a quick marriage and pregnancy: "Poppy, poppy, tell us the truth, for whom we marry". Of similar importance was cooking for the "female" celebration of Catherine the ceremonial, "fertilization" porridge with poppy (wives + husband), "to have as many guys as there is porridge with poppy" [3, p. 170-171]. Ritual seeding of the poppy occurred at night with a full moon (compare with the symbolism of the full moon). During the performance of the ritual, there was complete silence (analog of ritual darkness), which additionally indicates its erotic subtext.

In accordance with certain biological properties of the poppy, it could also be used in the magic of annihilation. During the wedding (at the beginning of fertilization), it was observed that one of the women (possible rivals) did not throw empty poppy heads (analog of the "empty" seed) in the direction of the bride, which could cause infertility. Such actions could be performed by the bride herself, when for certain reasons she did not want to become pregnant. In this case, she threw a nodule with poppy seeds (the motive for tying and stopping) to the well and said: "When this poppy comes up, then I'll give birth." Hence the origin of the phraseology "sit like a poppy", which is used on the territory of the Ukrainian and Belarusian Polesye to characterise old maidens.

Corresponding actions indicate ritual analogies between vegetative properties of poppy seeds with male seed, so drowning poppy in a well (enclosed space) provokes childlessness, and sowing (untied) poppy around the well (open space) contributes to faster fertilization. The maximum "breaking" of space is achieved by the fact that the girl crawled out with porridge at the gate - the higher she ascended, the more guys should appear. Cf. with the folkloric motives of treating a guy with water near the well, which corresponds to the motive of poppy seeding around the well: "Oh, drink, mother, that water that I have brought / Call the mother, that son-in-law that I fell in love with" [4, p. 133].

Hence the denomination of poppy seeds by masculine names in the Ukrainian round-the-clock game "Poppy", which is a rudiment of the ritual of causing rain (fertilization of the earth): "Makar drowned, Makar drowned $\langle\ldots\rangle$ screamed around, weeped like a deceased $<\ldots>$. Macar, son (sic!), get out of the water, spread the tears over the holy land". In this case, the spreading of poppy seeds (in the text, the flooding of "poppy tears") can be associated with getting rid of infertility / cessation of drought and modeling the future, subsequent fertilization, harvest. Similar motifs are also found in other rituals. In Volyn near the wedding caravan they put "whole" full poppy head (a hint of a future pregnancy). In bridal songs, the bride is compared with a poppy flower: "red as poppies", the tearing off of which symbolizes the loss of the girl's virtue: "A young boy got into poppy. / With poppies flowers plucked. / I threw it in the Danube-Sea. / The Danube River does not accept. / Nails to the shore ". Although the song is recorded in the Perm province, its East Slavic origin is obvious, as evidenced by the image of the Danube common in Ukrainian and Russian songs [3, p. 172-173].

The use of poppies as a symbol of fertility is one of the most common motifs of agricultural rites. During the drought, nine consecrated grains of "poppy" were poured "through the sleeve" or dropped into a bundle in a well. This should have been done by widows, advanced women or children, that is, those who are already or have not yet been involved in the process of procreation, since casting a poppy in a well could lead to infertility. The precipitation of the maximum amount of grain (nine is the largest number of natural numbers) through the ornamented sleeve of ceremonial clothes stimulates the "fertilization" of the 
earth, the growth of cereal crops and is compared with fairy tales about Vasilisa, which "sowed" the remains of ceremonial food from the sleeve: "Vasilisa the Wise went to dance with Ivan Tsarevich. She waved her left sleeve the lake became, waved her right - white swans swam along the lake. The Tsar and all the guests wondered miraculously". The corresponding actions are contrasted with those that are performed to prevent unwanted pregnancies, during which poppies throw childbearing women into the well. In this aspect, the binary opposition "childbearing / barren" is relevant, within which a ritual mystery is played out.

Together with the implementation of magical actions aimed at fertilization / infertility, an important element of traditional culture is the legitimization of sexual intercourse. Unauthorized sexual intercourse was subject to collective ostracism. Those who lost honesty, cut the scythe, cut the hem of clothes or the earlobe, caught in adultery led naked, publicly showing their nakedness, which forced violators to change their place of residence. Among the traditional punishments, the blinding of the head or the head with tar is a sign [5, p. 296]. It is likely that instead of the head it was allowed to smear the body as an antiseptic precaution, and the black color of the head indicated a possible carrier of infection. According to $\mathrm{N}$. Sumtsov, the use of tar can be a relic of the death penalty, when a thief was poured over with a combustible mixture, then drove through the village and then burned. The hypothesis of the scientist is confirmed by the annalistic evidence: "The same Theost (Hephaestus) established the law to wives: to have one husband and abstain ....". And who violates (the law) - that is thrown into a fiery furnace"[6, p. 10]. It is possible that the violator of traditional law was "withdrawn" from society - at first, by mocking him, relatives refused, after which he was burned as a possible carrier of infection. This way in ancient times could stop the deadly epidemics, which explains the sudden changes in the burial rite - the inhumation for cremation.

The death penalty for violating monogamy was practiced in the Magdeburg law: "Those caught in adultery must be truncated with a sword" [7, p. 129], the remains of which can be traced in the texts "from childhood insomnia": "On the field, the guy with the girl rocked, pumped over. Three came to them: Peter, and Paul, and the prophet Elijah: "It's enough for you to swing, it's enough to pump." And they did not listen to them. <...> therefore the Lord Himself came to them with knives, with their axes to slash "[8, No. 139].

Eliminating of excess, harmful. Associations with physiological cycles of cleansing the body are "used" by the rite as a means of eliminating the disease: "Lichen, lichen, I'll mix you with shit, your mother bitch, did not give you to suck her tits, you need to perish"; "When the fever comes from the water, go to the water, when from fright, then go to the ass" [8, No. 353-354, 567]. It is likely that such texts were pronounced in the process of emptying. For the expulsion of "mora", forty different fruits were collected, which were eaten one at a time during emptying. At the same time they said: «Ја једем (име воћке), а мора да издзе $г<$..>a) ("I eat (the name of the fruit), and let the mara eat shit"). Similar actions (only three times) had to be done in order to drive away the "living dead" from the dwelling [9, p. 438]. Consequently, feces were considered an effective protective agent, which was used in emergency cases of "rough" violation of borders with the otherworld. The disease was sent to the "other world" by mixing with organic waste, which means throwing them into unclean, detached places, deprived of any cultural overtones (destruction to the level of excrement). Cf. with sentences aimed at the destruction of the disease: $\langle\Gamma<\ldots>$ ты в грлу» / «Г< ..> ты в глаз» (серб.) [9, c. 438]. Similar subjects form binary oppositions to the texts "on happy births", where the "bitch" is opposed to the mother, and shit - to gold, therefore, provide the opposite to the birth result - "lichen <...> you must perish". Similar semantic variations are found in the interpretation of dreams, where feces are associated with money or gold.

When the subjects of mixing as a means of total destruction are contrasted with maternity ceremonies, then the texts with the semantics of exposure are wedding (the magic of fertilization), namely, planting young people on a "shaggy" sheepskin coat: "They sit down on the patient's face with a bare back and say: naked (unprotected), like my naked ass"[8, No. 470-471]. Comparison of the bare buttocks with the disease is compared with the rituals of applying the "bare" dead bone: "You go to the vine, take a whole bone, as it lies. Do it, and put it, do not turn it in the other direction. Knock on warts: "Like this bone is naked, so the arm was naked, without warts" [8, No. 348]. In the magic of fertilization, fertility, shaggy means wealth, prosperity. Thus, at Epiphany, the master dressed the sheepskin inside out and went round the cattle; during the harvest left the last sheaf to"Veles (the ancient god) for the beard".

Another semantic color gets urine, as evidenced by the texts "from an evil glance": "Under the breast you do not feel sick, do not dry your hearts, do not burn faces, squeeze out of bone, out of urine". In some texts "urine" varies with blood: "I speak out of yellow bone, from hot blood" [8, No. 243-244]. Corresponding analogies are explained by the fact that "urine" and blood is bodily moisture equivalent to natural moisture: Old Rusian моча - "rainy weather", Slovenian moća, Polish mocz, Upper Lusatian moć "moisture" [10, c. 666], Ukrainian мочар - "мокрое место", мочва - "slush" [11, p. 451]. In this regard, it was also used as a protective agent. Unlike feces, the use of urine was limited. With its help, they "marked" only living (not otherworldly) beings, thus affirming "ownership" in front of invisible forces. For example, from the evil eye the mother washed a child's face with her urine (Polissya), the owner, after acquiring a pair of oxen, had to irrigate them with his own urine, so that "no one spoiled by an unkind look" (Serbia) [12, p. 309]. The corresponding actions are compared with the instinctive behavior of mammals that "sweep" the the territory with urine. In this aspect, ritual comparisons of the urine (the moisture of the bottom) with saliva (the moisture of the top), which smeared the forehead of the sick child, seem reasonable: "After a meeting with a harmful person, the mother licked the forehead of the child three times with a tongue, then spit three times" [13, p. 17-18].

A separate place is occupied by actions with a demonstration of the corporal lower body, which were also considered a method of ritual protection. When the hail of clouds approached (Hala), the hostess came out to meet her, and, with her skirt lifted, said: "Run a miracle from a miracle wonderful! You can not be around "(Serbia, Bulgaria). Thus, in the rite of protection against hail, the female corporeal bottom acts as an attribute of the cosmic bottom (land), its demonstration leveling the redundancy of the top (hail clouds). The corresponding exposure forms a binary opposition: cloud / top / "miracle" - vagina / bottom 
/ "miracle". Rudiments of similar ceremonies are fixed in the texts "from an evil glance" with the difference that the attribute of the cosmic bottom is illness.

Conclusions. In mythology, a double relation to the body lower is fixed, which ranges from positive, useful, pure to negative, harmful, unclean. In the first case, semantic codes symbolize the processes of fertilization, birth, in the second - getting rid of impure, superfluous.

The mythology of fertilization correlates with agricultural cults and is demonstrated by the example of small and numerous grains of poppy, which is associated with the male seed. Sowing of poppy seed around cultural objects with female symbolism (well) provokes fertilization, pregnancy, the spreading of poppies near natural objects (reservoirs, "Danube") - rain. Performing the opposite actions with the restriction semantics (tying, drowning) leads to the reverse consequences and is compared with female infertility.

Unlike fertilization, birth, adultery ("misuse" of reproductive organs) is perceived at the level of social disease. Ritual methods of preventing adultery resemble ways to counteract fatal epidemics (disinfection, burning).

The next part of the opposition is the actions that are carried out with the goal of deducing the impure, including as a way to destroy the disease. Specific places here represent impurity, filth and rot, therefore they are associated with the other world. Hence the protective semantics of the corporeal bottom in the rituals of scaring away thunderclouds (harmful moisture).

\section{ЛИТЕРАТУРА}

1. Подорога В. Феноменология тела. Введение в философскую антропологию. М., 1995. - С. 9-98; Чеснов Я.В. Культурогенное значение инверсий тела // Философские науки. - 2007. - №8. - С. 33-46; Тело в русской культуре: сб. статей. - М., 2005. - 399 с.

2. Тіло в текстах культур. Студії з культурної антропології. К., 2003. - 222 с.; Бербулєску К. Топографія людського тіла. Нога. Рука // Народна творчість та етнологія. - 2011. №2. - С. 47-51; Кириленко Е.И. Архитектоника человеческого тела: культурно-символический аспект // Вестник ТГПУ(ТSPU Bulletin). - 2013, - № 9 (137). C. 241-248. Ігнатенко І. Жіноче тіло в сучасних культурноантропологічних дослідженнях етнологів України й Росії // Вісник Київського національного університету імені Тараса Шевченка. Серія: Історія. - Вип. 108. - К., 2011. C. 20-22.

3. Усачёва В.В. Мак // Славянские древности: этнолингвистический словарь: в 5 т.. - М., 2004. - Т. 3. - С. 170-174.

4. Костомаров Н. Славянская мифология. Исторические монографии и исследования. - М., 1995. - 688 с.

5. Сумцов Н.Ф. Культурные переживания // Киевская старина. - 1889. - T. XXVII. - ноябрь. - С. 280-327.

6. Рыбаков Б.А. Язычество древних славян. - М., 1994. - 608 c.

7. Василенко Н. Право Магдебургское // Энциклопедический словарь. - СПб., 1898. - Т. 48. - 436с.

8. Полесские заговоры (в записях 1970-1990-х гг.). - М., 2003. $-752 \mathrm{c}$.

9. Левкиевская Е.Е. Кал // Славянские древности: этнолингвистический словарь : в 5 т.. - М., 1999. - Т. 2. C. $437-439$

10. Фасмер М. Этимологический словарь русского языка :в 4 т. - М. - T. 2 - 1986.- 672 c.

11. Словарь української мови: у 4 т. - К. - Т. 2. - 1996. - 588 с.

12. Левкиевская Е.Е. Моча // Славянские древности: этнолингвистический словарь: в 5 т. - М., 2004. - Т. 3. C. 309-311.

13. Іванов О.В. Селянські замовляння («пристріт» або «вроки» i «переляк»). 1930 р. - Рукописні фонди ІМФЕ ім. М.Т Рильського НАН України. - Ф. 1-4. 298. 18 арк.

\section{REFERENSES}

1. Podoroga V. Phenomenology of the body. Introduction to philosophical anthropology. M., 1995. - P. 9-98; Chesnov Ya.V. Cultural significance of body inversions // Philosophical sciences. - 2007. - №8. - P. 33-46; The body in Russian culture: Sat. articles. - M., 2005. - 399 p.

2. Body in the texts of cultures. Studios on cultural anthropology. K., 2003. - $222 \mathrm{~s}$.; K. Berbulescu Topography of the human body. Leg. Hand // Popular creativity and ethnology. - 2011. №2. - P. 47-51; Kirilenko Ye.I. Architectonics of the human body: a cultural and symbolic aspect // The Bulletin of the TSPU (TSPU Bulletin). - 2013, - No. 9 (137). - pp. 241-248. Ignatenko I. The female body in modern culturalanthropological studies of ethnologists of Ukraine and Russia // Bulletin of Taras Shevchenko National University. Series: History. - Ed. 108. - K., 2011. - P. 20-22.

3. Usachev V.V. Poppy // Slavic antiquities: ethnolinguistic dictionary: in 5 t. - M., 2004. - V. 3. - P. 170-174.

4. Kostomarov N. Slavic mythology. Historical monographs and studies. - M., 1995. - 688 p.

5. Sumtsov N.F. Cultural experiences // Kiev's antiquity. - 1889. V. XXVII. - November. - P. 280-327.

6. Rybakov B.A. Paganism of the ancient Slavs. - M., 1994. - 608 p.

7. Vasilenko N. Magdeburg Law // Encyclopedic Dictionary. SPb., 1898. - V. 48. - 436 p.

8. Polesye conspiracies (in the records of 1970-1990-ies.). - M., 2003. - $752 \mathrm{p}$.

9. Levkiyevskaya Ye.Ye. Feces // Slavic antiquities: ethnolinguistic dictionary: in 5 t. - M., 1999. - V. 2. - P. 437439.

10. Fasmer M. Etymological dictionary of the Russian language: in 4 volumes - M. - V. 2 - 1986.- 672 p.

11. Словник української мови: у 4 т. - К. - Т. 2. - 1996. -588 с.

12. Levkievskaya Ye.Ye. Urine // Slavic antiquities: ethnolinguistic dictionary: in 5 volumes - M., 2004. - V. 3. - P. 309-311.

13. Ivanov O.V. Peasant ordering ("ghost" or "tricks" and "fear"). 1930 - Handwritten funds of M.T. Rylsky IMFE, National Academy of Sciences of Ukraine. - F. 1-4. 298. 18 p.

\section{Текст тела: оппозиция «чистый/нечистый» в мифологических представлениях славян}

\section{А. И. Темченко}

Аннотация. В мифологии фиксируется двойственное отношение к телу, которое колеблется в диапазоне от позитивного, полезного, чистого к негативному, вредному, нечистому. В первом случае смысловые коды определяют процессы зачатия и рождения, во втором - избавление от нечистого и лишнего. Мифология зачатия соотносится с земледельческими культами и представлена на примере зёрен мака. В обрядах рождения символика тела в определенных аспектах пересекается с семантическим полем мифологического верха.

Магические действия избавления от нечистого «используются» обрядом как способ уничтожения болезни.

Ключевые слова: миф, тело, мак, Царские врата, сакральные покровители. 